\title{
Special Issue: Intramolecular Hydrogen Bonding 2017
}

\author{
Steve Scheiner \\ Department of Chemistry and Biochemistry, Utah State University, Logan, UT 84322-0300, USA; \\ steve.scheiner@usu.edu; Tel.: +1-435-797-7419
}

Received: 8 September 2017; Accepted: 10 September 2017; Published: 11 September 2017

Even after more than a century of study [1-6], scrutiny, and detailed examination, the H-bond continues [7-12] to evoke a level of fascination that surpasses many other phenomena. Perhaps it is the ability of the simple $\mathrm{H}$ atom, with but a single electron, to act as a glue that maintains contact between much more complicated species. Or it might be its geometry, which prefers to hold the bridging proton on a direct line between the two heavy atoms. Not to be ignored are the spectral features of the H-bond: the large red shift of the stretching frequency of the covalent $\mathrm{A}-\mathrm{H}$ bond, coupled with its intensification, or the downfield shift of the proton's NMR signal. Yet study of this bond is far from complete, with one surprise after another continuing to emerge. As it turns out, the aforementioned red shift, for example, long considered as the trademark of this bond, is not so characteristic after all. $\mathrm{H}$-bonds that shift in the opposite direction, to the blue, have been observed [13-16] in a variety of systems. The long held belief that only very electronegative atoms like $\mathrm{F}, \mathrm{O}$, and $\mathrm{N}$ can participate in these bonds has been shattered, as one atom after another, $\mathrm{S}$ and $\mathrm{Cl}$ and even metals to name just a few, have been added [17-20] to the rapidly growing list.

While H-bonds are typically conceived as interactions between pairs of molecules, there is no reason whatsoever why they cannot occur within the confines of a single molecule. Indeed, such intramolecular $\mathrm{H}$-bonds are treated as fundamental underpinnings of the structure and function of such stalwart biomolecules [21-23] as proteins, nucleic acids, and carbohydrates. Despite their wide occurrence, intramolecular H-bonds have been studied far less than their intermolecular cousins. One reason for this less robust literature is a set of complications that cloud the interpretation of the data. In the avenue of quantum calculations, for example, a bulwark of the characterization of any interaction such as an $\mathrm{H}$-bond is the energy required to break it. However, the definition of the $\mathrm{H}$-bond energy for an intramolecular $\mathrm{H}$-bond is fraught with complications, and has engendered a number of different approaches, one could almost say 'tricks', to seek an accurate and reliable means of its estimation.

It is to this subject of intramolecular H-bonds that this issue is devoted. There are a number of review articles that summarize the current state of the art in various disciplines. Oksanen et al. explain how neutron crystallography can be applied to such bonds in the context of large macromolecules [24]. Hansen and Spanget-Larsen review progress in the application of NMR and IR in the context of particularly strong H-bonds [25]. The manner in which quantum calculations can mesh with experimental approaches is summarized by Siskos et al. [26]. The involvement of one particular element, F, is described in some detail by Mishra and Suryaprakash [27], and Sobczyk et al. review a select group of intramolecular H-bonds [28].

Aside from these review articles, the issue contains a wide variety of reports of new studies. Quantum calculations are an important means to analyze interactions such as these and the influence of such calculations represents a common theme in much of the work described here. Quiquempoix et al. look at levoglucosan and its derivatives [29], while variously substituted aminobenzamides come under the scrutiny of Mphahlele et al. [30]. Mammino considers the relevance of these interactions to an antioxidant [31]; the possibility of multiple intramolecular H-bonds, and their relevance to regioisomers, is discussed by Martínez-Cifuentes et al. [32]. Rusinska-Roszak [33] focuses on the 
relation between these bonds and aromaticity, while lactams are the subject of the contribution by Mejia et al. [34]. Bilonda and Mammino apply their calculations to quinine [35], and the naphthalene series is examined by Sanchez-Sanz et al. who compare H-bonds to their chalcogen analogues [36]. Scheiner explains how quantum calculations of NMR data can provide unambiguous evidence of H-bonds, as well as their strength [37]. In addition to quantum calculations, methods of dynamics can also be useful, as explained by Huang et al. [38].

It is hoped that this select list of reports and review articles will provide the reader with some perspective on the field of intramolecular H-bonds. Some of this work may perhaps inspire others to pursue threads that remain open in this area, with many lingering questions that beg for answers.

Conflicts of Interest: The author declares no conflict of interest.

\section{References}

1. Kumler, W.D. The Effect of the Hydrogen Bond on the Dielectric Constants and Boiling Points of Organic Liquids. J. Am. Chem. Soc. 1935, 57, 600-605. [CrossRef]

2. Gordy, W. Infrared absorption studies of hydrogen bonds between unlike molecules. J. Am. Chem. Soc. 1938, 60, 605-612. [CrossRef]

3. Badger, R.M.; Bauer, S.H. Spectroscopic studies of the hydrogen bond. II. The shifts of the O-H vibrational frequency in the formation of the hydrogen bond. J. Chem. Phys. 1939, 5, 839-851. [CrossRef]

4. Pimentel, G.C.; McClellan, A.L. The Hydrogen Bond; Freeman: San Francisco, CA, USA, 1960.

5. Sutor, D.J. The C-H $\cdots$ O hydrogen bond in crystals. Nature 1962, 195, 68-69. [CrossRef]

6. Krimm, S. Hydrogen Bonding of $\mathrm{C}-\mathrm{H} \cdots \mathrm{O}=\mathrm{C}$ in Proteins. Science 1967, 158, 530-531. [CrossRef] [PubMed]

7. Kollman, P.A.; Allen, L.C. The theory of the hydrogen bond. Chem. Rev. 1972, 72, 283-303. [CrossRef]

8. Joesten, M.D.; Schaad, L.J. Hydrogen Bonding; Marcel Dekker: New York, NY, USA, 1974; p. 622.

9. Schuster, P.; Zundel, G.; Sandorfy, C. The Hydrogen Bond. Recent Developments in Theory and Experiments; North-Holland Publishing Co.: Amsterdam, The Netherlands, 1976.

10. Schuster, P. Hydrogen Bonds; Springer: Berlin, Germany, 1984; Volume 120, p. 117.

11. Grabowski, S.J. Hydrogen Bonding — New Insights; Springer: Dordrecht, The Netherlands, 2006.

12. Gilli, G.; Gilli, P. The Nature of the Hydrogen Bond; Oxford University Press: Oxford, UK, 2009; p. 313.

13. Murray, J.S.; Concha, M.C.; Lane, P.; Hobza, P.; Politzer, P. Blue shifts vs. red shifts in s-hole bonding. J. Mol. Model. 2008, 14, 699-704. [CrossRef] [PubMed]

14. Karpfen, A.; Kryachko, E.S. On the intramolecular origin of the blue shift of A-H stretching frequencies: Triatomic hydrides HAX. J. Phys. Chem. A 2009, 113, 5217-5223. [CrossRef] [PubMed]

15. Trung, N.T.; Hue, T.T.; Nguyen, M.T. Remarkable blue shifts of $\mathrm{C}-\mathrm{H}$ and N-H stretching frequencies in the interaction of monosubstituted formaldehyde and thioformaldehyde with nitrosyl hydride. J. Phys. Chem. A 2009, 113, 3245-3253. [CrossRef] [PubMed]

16. Hobza, P. N-H $\cdots$ F improper blue-shifting H-bond. Int. J. Quantum Chem. 2002, 90, 1071-1074. [CrossRef]

17. Arunan, E.; Desiraju, G.R.; Klein, R.A.; Sadlej, J.; Scheiner, S.; Alkorta, I.; Clary, D.C.; Crabtree, R.H.; Dannenberg, J.J.; Hobza, P.; et al. Definition of the Hydrogen Bond. Pure Appl. Chem. 2011, 83, 1637-1641. [CrossRef]

18. Andrić, J.M.; Misini-Ignjatović, M.Z.; Murray, J.S.; Politzer, P.; Zarić, S.D. Hydrogen Bonding between Metal-Ion Complexes and Noncoordinated Water: Electrostatic Potentials and Interaction Energies. ChemPhysChem 2016, 17, 2035-2042. [CrossRef] [PubMed]

19. Kryachko, E.S. Where gold meets a hydrogen bond? J. Mol. Struct. 2008, 880, 23-30. [CrossRef]

20. Kozelka, J. Agostic and Hydrogen-Bonding $\mathrm{X}-\mathrm{H} \cdots \mathrm{M}$ Interactions Involving a $\mathrm{d}^{8}$ Metal Center: Recent Advances Towards Their Understanding. In Noncovalent Forces; Scheiner, S., Ed.; Springer: Dordrecht, The Netherlands, 2015; Volume 19, pp. 129-158.

21. Baker, E.N.; Hubbard, R.E. Hydrogen bonding in globular proteins. Prog. Biophys. Mol. Biol. 1984, 44, 97-179. [CrossRef]

22. Jeffrey, G.A.; Yeon, Y. The correlation between hydrogen bond lengths and proton chemical shifts in crystals. Acta Crystallogr. 1986, B42, 410-413. [CrossRef]

23. Jeffrey, G.A.; Saenger, W. Hydrogen Bonding in Biological Structures; Springer: Berlin, Germany, 1991. 
24. Oksanen, E.; Chen, J.-H.; Fisher, S.Z. Neutron Crystallography for the Study of Hydrogen Bonds in Macromolecules. Molecules 2017, 22, 596. [CrossRef] [PubMed]

25. Hansen, P.E.; Spanget-Larsen, J. NMR and IR Investigations of Strong Intramolecular Hydrogen Bonds. Molecules 2017, 22, 552. [CrossRef] [PubMed]

26. Siskos, M.G.; Choudhary, M.I.; Gerothanassis, I.P. Hydrogen Atomic Positions of O-H...O Hydrogen Bonds in Solution and in the Solid State: The Synergy of Quantum Chemical Calculations with ${ }^{1} \mathrm{H}-\mathrm{NMR}$ Chemical Shifts and X-ray Diffraction Methods. Molecules 2017, 22, 415. [CrossRef] [PubMed]

27. Mishra, S.K.; Suryaprakash, N. Intramolecular Hydrogen Bonding Involving Organic Fluorine: NMR Investigations Corroborated by DFT-Based Theoretical Calculations. Molecules 2017, 22, 423. [CrossRef] [PubMed]

28. Sobczyk, L.; Chudoba, D.; Tolstoy, P.M.; Filarowski, A. Some Brief Notes on Theoretical and Experimental Investigations of Intramolecular Hydrogen Bonding. Molecules 2016, 21, 1657. [CrossRef] [PubMed]

29. Quiquempoix, L.; Bogdan, E.; Wells, N.J.; Le Questel, J.-Y.; Graton, J.; Linclau, B. A Study of Intramolecular Hydrogen Bonding in Levoglucosan Derivatives. Molecules 2017, 22, 518. [CrossRef] [PubMed]

30. Mphahlele, M.J.; Maluleka, M.M.; Rhyman, L.; Ramasami, P.; Mampa, R.M. Spectroscopic, DFT, and XRD Studies of Hydrogen Bonds in N-Unsubstituted 2-Aminobenzamides. Molecules 2017, 22, 83. [CrossRef] [PubMed]

31. Mammino, L. Intramolecular Hydrogen Bonding and Conformational Preferences of Arzanol-An Antioxidant Acylphloroglucinol. Molecules 2017, 22, 1294. [CrossRef] [PubMed]

32. Martínez-Cifuentes, M.; Cardona, W.; Saitz, C.; Weiss-López, B.; Araya-Maturana, R. A Study about Regioisomeric Hydroquinones with Multiple Intramolecular Hydrogen Bonding. Molecules 2017, $22,593$. [CrossRef] [PubMed]

33. Rusinska-Roszak, D. Energy of Intramolecular Hydrogen Bonding in ortho-Hydroxybenzaldehydes, Phenones and Quinones. Transfer of Aromaticity from ipso-Benzene Ring to the Enol System(s). Molecules 2017, 22, 481. [CrossRef] [PubMed]

34. Mejía, S.; Hernández-Pérez, J.M.; Sandoval-Lira, J.; Sartillo-Piscil, F. Looking Inside the Intramolecular $\mathrm{C}-\mathrm{H} \cdots \mathrm{O}$ Hydrogen Bond in Lactams Derived from $\alpha$-Methylbenzylamine. Molecules 2017, $22,361$. [CrossRef] [PubMed]

35. Bilonda, M.K.; Mammino, L. Intramolecular Hydrogen Bonds in Conformers of Quinine and Quinidine: An HF, MP2 and DFT Study. Molecules 2017, 22, 245. [CrossRef] [PubMed]

36. Sánchez-Sanz, G.; Alkorta, I.; Elguero, J. Theoretical Study of Intramolecular Interactions in Peri-Substituted Naphthalenes: Chalcogen and Hydrogen Bonds. Molecules 2017, 22, 227. [CrossRef] [PubMed]

37. Scheiner, S. Assessment of the Presence and Strength of H-Bonds by Means of Corrected NMR. Molecules 2016, 21, 1426. [CrossRef] [PubMed]

38. Huang, I.-S.; Li, J.-J.; Tsai, M.-K. Solvation Dynamics of $\mathrm{CO}_{2}(\mathrm{~g})$ by Monoethanolamine at the Gas-Liquid Interface: A Molecular Mechanics Approach. Molecules 2017, 22, 8. [CrossRef] [PubMed] 